\title{
Domestic and Foreign Ownership of Private Sector in Mixed Duopoly
}

\author{
Kazuhiro Ohnis hi
}

Institute for Basic Economic Science, Minoo, Osaka 562-0044, Japan

\begin{abstract}
This paper considers a quantity-setting mixed market model in which a public firm co mpetes with a private firm. The paper examines the welfare effects of do mestic and foreign ownership of the private firm. The paper shows that social welfare is maximized by full domestic ownership of the private firm, while consumer surplus is maximized by full foreign ownership of the private firm.
\end{abstract}

Keywords Mixed Duopoly, Full Do mestic Ownership, Partial Domestic Ownership, Full Fore ign Ownership

\section{Introduction}

As is very well known, mixed oligopolies are common in developed and developing countries as well as in former communist countries. Public firms compete with domestic and/or foreign private firms in many industries, such as the airline, banking, broadcasting, education, electricity, health care, home loans, life insurance, overnight delivery, rail, shipbuilding, telecommunications, and tobacco. For example, in the tobacco industries of France, Italy, Russia, Spain, Austria, Turkey, China, Japan, etc., we can find real-world examples in which public firms compete or competed against each other and other private firms such as Philip Morris and R. J. Reynolds. In the Norwegian oil industry, the state-owned Statoil competes against two multinational corporations Esso Norge and Norske Shell (see[1]). Furthermore, Krugman and Obstfeld[2] describe foreign ownership as "In U.S. statistics, a U.S. company is considered foreign-controlled, and therefore a subsidiary of a fore ign-based multinational, if 10 persent or more of stock is held by a foreign company; the idea is that 10 persent is enough to convey effective control."

The pioneering theoretical work on a welfare-maximizing public firm was done by [3]. Since then, the analysis of mixed market models that incorporate welfare-maximizing public firms has received increasing attention and has been widely performed by many researchers (see[4-8] for excellent surveys). Most studies are mixed models with domestic private firms (see, for examp le, [9-30]).

Some resent studies include foreign private firms (see, for example,[31-38]. These studies does not consider partial

* Corresponding author:

ohnishi@e.people.or.jp (Kazuhiro Ohnishi)

Published online at http $/ /$ journal.sapub.org/m2economics

Copyright (C) 2012 Scientific \& Academic Publishing. All Rights Reserved foreign ownership of private firms. Fjell and Pal[1] suggest that a fraction of the foreign firm's profits can be included in the domestic social welfare function. Fernández-Ruiz[39] investigates firms' decisions to hire managers in a duopoly where a public firm competes with a foreign private firm. He then considers a situation in which a fraction of the foreign private firm's profits can be included in the domestic social welfare function.

We consider a quantity-setting mixed market model in which a public firm with social welfare objectives competes with a private firm with profit objectives. We examine the welfare effects of domestic and foreign ownership of the private firm. We show that social welfare is maximized by full do mestic ownership of the private firm, while consumer surplus is maximized by full fore ign ownership of the private firm. As a result of these, we find that neither consumer surplus nor social welfare is maximized by partial foreign ownership of the private firm.

The remainder of this paper is organized as follows. In Section 2, we describe a mixed duopoly model with a public firm and a private firm. Section 3 examines the welfare effect of domestic and foreign ownership of the private firm in the model. Finally, Section 4 concludes the paper.

\section{The Model}

Let us consider a mixed duopoly model with one public firm and one private firm. In the remainder of this paper, subscripts 0 and 1 denote the public firm and the private firm, respectively. There is no possibility of entry or exit. The duopolists produce perfectly subsitutable commodities. The inverse demand function is given by $P=10-Q$, where $P$ is the market price, and $Q$ is the total quantity of output in the market.

Each firm's profit $\pi_{i}$ is given by 


$$
\pi_{i}=P q_{i}-m_{i} q_{i} \quad(i=0,1),
$$

where $q_{i}$ represents firm $i$ 's output, and $m_{i}$ is firm $i$ 's constant marginal cost. We assume that the public firm is less efficient than the private firm, i.e. $0<m_{1}<m_{0}{ }^{1}$ For simplicity, we normalize $m_{0}$ to one and $m_{1}$ to zero. The private firm aims to maximize its own profit.

Domestic social welfare $W$ is the sum of consumer surplus and producer surplus, and is given by

$$
W=\frac{Q^{2}}{2}+\pi_{0}+\lambda \pi_{1},
$$

where $Q^{2} / 2$ denotes consumer surplus, and $\lambda \in[0,1]$ is the level of domestic ownership. If $\lambda=1$, the private firm is domestic owned. On the other hand, if $\lambda=0$, the private firm is foreign owned and its profit is excluded from domestic social welfare. The public firm aims to maximize domestic social welfare. In this paper, we analyze the Nash equilibrium of the quantity-setting mixed duopoly model.

\section{Results}

We first present the equilib rium values of outputs and the price, obtained by maximizing (1) and (2) simultaneously:

$$
\begin{gathered}
q_{0}=\frac{2(9-5 \lambda)}{2-\lambda}, \\
q_{1}=\frac{1}{2-\lambda}, \\
Q=\frac{19-10 \lambda}{2-\lambda}, \\
P=\frac{1}{2-\lambda} . \\
\pi_{0}=\frac{2\left(-9+14 \lambda-5 \lambda^{2}\right)}{(2-\lambda)^{2}}, \\
\pi_{1}=\frac{1}{(2-\lambda)^{2}} .
\end{gathered}
$$

The maximization of $\pi_{0}$ with respect to $\lambda$ is derived from $d \pi_{0} / d \lambda$. That is, we have $\lambda=5 / 3 \approx 1.667$. When $\lambda=0, \pi_{0}=-4.5$, and when $\lambda=1, \pi_{0}=0$. When $0 \leq \lambda \leq 1, \pi_{0}$ is a strictly increasing function of $\lambda$. From (8), we easily see that when $0 \leq \lambda \leq 1, \pi_{1}$ is a strictly increasing function of $\lambda$.

Third, we consider domestic consumer surplus, which can be expressed as follows:

\footnotetext{
1 This assumption is justified in[8, 13, 40], and is often used in literature studying mixed markets. See, for instance,[15, 18, 19, 22, 23, 27, 33, 37, 39]. Let us assume that the public firm is equally or more efficient than the private firm. In this case, since the public firm, which is interested in social welfare, has a higher incentive to underbid an opponent's price than the private firm would have, the public firm chooses $q_{0}$ such that price equals marginal cost. Therefore, the private firm has no incentive to operate in the market, and the public firm supplies the entire market, resulting in a wel fare-maximizing public monopoly. This assumption is made to eliminate such a trivial solution.
}

$$
C S=\frac{(19-10 \lambda)^{2}}{2(2-\lambda)^{2}} .
$$

When $\lambda=0, C S=45.125$, and when $\lambda=1$, $C S=40.5$. $C S$ is illustrated in Graph 1 as a function of $\lambda$. That is, when $0 \leq \lambda \leq 1, C S$ is a strictly decreasing function of $\lambda$.

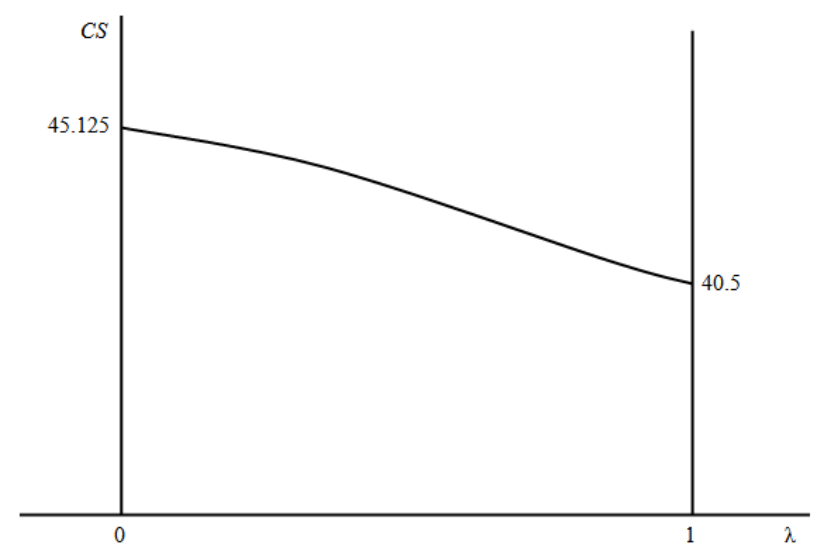

Graph 1. The level of domestic ownership and consumer surplus.

Fourth, domestic social welfare can be expressed as follows:

$$
W=\frac{327-324 \lambda+80 \lambda^{2}}{2(2-\lambda)^{2}} .
$$

The maximization of $W$ with respect to $\lambda$ is derived from $d W / d \lambda$. That is, we have $\lambda=1.5 . W$ is illustrated in Graph 2 as a function of $\lambda$. When $\lambda=0, W=40.875$, and when $\lambda=1, W=41.5$. That is, when $0 \leq \lambda \leq 1, W$ is a strictly increasing function of $\lambda$.

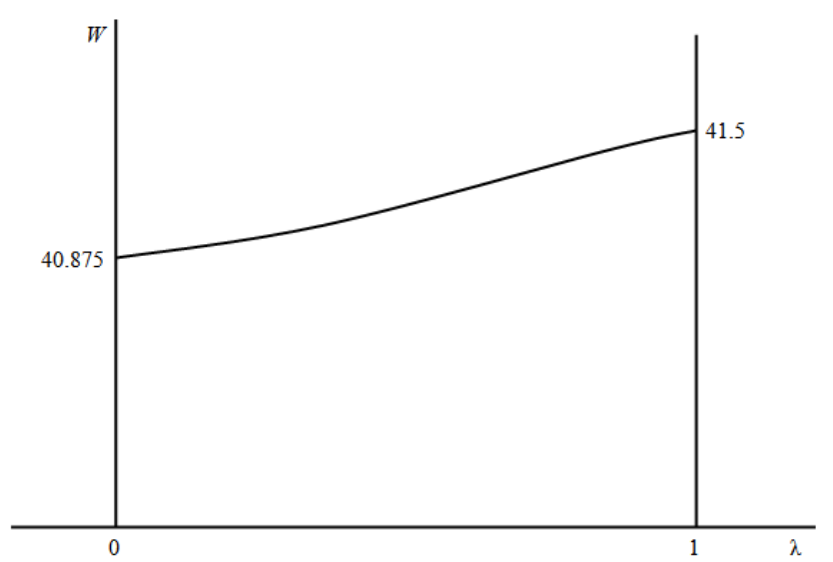

Graph 2. The level of domestic ownership and social welfare.

We can now state the following proposition.

Proposition 1. In the mixed market model with one public firm and one private firm, (i) consumer surplus is maximized by full foreign ownership of the private firm, and (ii) social welfare is maximized by full domestic ownership of the private firm.

This proposition indicates that neither consumer surplus nor social welfare is maximized by partial domestic ownership of the private firm. 


\section{Conclusions}

We have considered a quantity-setting mixed market model in which a welfare-maximizing public firm competes with a profit-maximizing private firm. We have examined the welfare effects of domestic and foreign ownership of the private firm. We have then demonstrated that social welfare is maximized by full do mestic ownership of the private firm, while consumer surplus is maximized by full foreign ownership of the private firm.

\section{REFERENCES}

[1] Fjell, K., Pal, D., "A Mixed Oligopoly in the Presence of Foreign Private Firms", Wiley-Blackwell, Canadian Journal of Economics, vol. 29, no. 3, pp. 737-743, 1996.

[2] Krugman, P. R., Obstfeld, M., International Economics: Theory and Policy, Pearson, USA, 2009.

[3] Merrill, W., Schneider, N., "Government Firms in Oligopoly Industries", Oxford University Press, Quarterly Journal of Economics, vol. 80, no. 3, pp. 400-412, 1966.

[4] Bös, D., Public Enterprise Economics, Elsevier Science, Holland, 1985.

[5] Bös, D., Privatization: A Theoretical Treatment, Clarendon Press, UK, 2001.

[6] Vickers, J., Yarrow, G., Privatization: An Economic Analy sis, MIT Press, USA, 1988.

[7] Cremer, H., Marchand, M., Thisse, J.-F., "The Public Firm as an Instrument for Regulating an Oligopolistic Market", Oxford University Press, Oxford Economic Papers, vol. 41, no. 2, pp. 283-301, 1989.

[8] Nett, L., "Mixed Oligopoly with Homogeneous Goods", Wiley-Blackwell, Annals of Public and Cooperative Economics, vol. 64, no. 3, pp. 367-393, 1993.

[9] Harris, R. G., Wiens, E, G., "Government Enterprise: An Instrument for Internal Regulation of Industry", Wiley-Blackwell, Canadian Journal of Economics, vol. 13, no. 1, pp. 125-132, 1980.

[10] Ware, R., "A Model of Public Enterprise with Entry", Wiley-Blackwell, Canadian Journal of Economics, vol. 19, no. 1, pp. $642-655,1986$.

[11] Cremer, H., Marchand, M., Thisse, J.-F., "Mixed Oligopoly with Differentiated Products", Elsevier, International Journal of Industrial Organization, vol. 9, no. 1, pp. 43-53, 1991.

[12] Delbono, F., Denicolò, V., "Regulating Innovative Activity: The Role of Public Firm", Elsevier, International Journal of Industrial Organization, vol. 11, no. 1, pp. 35-48, 1993.

[13] Nett, L., "Why Private Firms Are More Innovative Than Public Firms", Elsevier, European Journal of Political Economy, vol. 10, no. 4, pp. 639-653, 1994.

[14] Willner, J., "Welfare Maximization with Endogenous Average Costs", Elsevier, International Journal of Industrial Organization, vol. 12, no. 3, pp. 373-386, 1994.
[15] George, K., La Manna, M., "Mixed Duopoly, Inefficiency, and Public Ownership", Springer, Review of Industrial Organization, vol. 11, no. 6, pp. 853-860, 1996.

[16] White, M. D., "Mixed Oligopoly, Privatization and Subsidization", Elsevier, Economics Letters, vol. 53, no. 2, pp. 189-195, 1996.

[17] Anderson, S. P., de Palma, A., Thisse, J.-F., "Privatization and Efficiency in a Differentiated Industry", Elsevier, European Economic Review, vol. 41, no. 9, pp. 1635-1654, 1997.

[18] Mujumdar, S., Pal, D., "Effects of Indirect Taxation in a Mixed Oligopoly", Elsevier, Economics Letters, vol. 58, no. 2, pp. 199-204, 1998.

[19] Pal, D., "Endogenous Timing in a Mixed Oligopoly", Elsevier, Economics Letters, vol. 61, no. 2, pp. 181-185, 1998.

[20] Poyago-Theotoky, J., "R\&D Competition in a Mixed Duopoly under Uncertainty and Easy Imitation", Elsevier, Journal of Comparative Economics, vol. 26, no. 3, pp. 415-428, 1998

[21] Wen, M., Sasaki, D., "Would Excess Capacity in Public Firms Be Socially Optimal?", Wiley-Blackwell, Economic Record, vol. 77, no. 238, pp. 283-290, 2001.

[22] White, M. D., "Managerial Incentives and the Decision to Hire Managers in Markets with Public and Private Firms", Elsevier, European Journal of Political Economy, vol. 17, no. 4, pp. 887-896, 2001.

[23] Nishimori, A., Ogawa, H., "Public Monopoly, Mixed Oligopoly and Productive Efficiency", Wiley-Blackwell, Australian Economic Papers, vol. 41, no. 2, pp. 185-190, 2002.

[24] Bárcena-Ruiz, J. C., Garzón,M. B., "Mixed Duopoly, Merger and Multiproduct Firms", Springer, Journal of Economics, vol. 80 , no. 1, pp. 27-42, 2003.

[25] Matsumura, T., Matsushima, N., "Mixed Duopoly with Product Differentiation: Sequential Choice of Location", Wiley-Blackwell, Australian Economic Papers, vol. 42, no. 1, pp. 18-34, 2003.

[26] Matsumura, T., Kanda, O., "Mixed Oligopoly at Free Entry Markets", Springer, Journal of Economics, vol. 84, no. 1, pp. 27-48, 2005.

[27] Ohnishi, K., A Mixed Duopoly with a Lifetime Employment Contract as a Strategic Commitment", Mohr Siebeck, FinanzArchiv, vol. 62, no. 1, pp. 108-123, 2006.

[28] Artz, B., Heywood, J. S., McGinty, M., "The Merger Paradox in a Mixed Oligopoly", Elsevier, Research in Economics, vol. 63, no. 1, pp. 1-10, 2009.

[29] Heywood, J. S., Ye, G., "Mixed Oligopoly, Sequential Entry, and Spatial Price Discrimination", Wiley-Blackwell, Economic Inquiry, vol. 47, no. 3, pp. 589-597, 2009.

[30] Roy chowdhury, P., "Mixed Oligopoly with Distortions: First Best with Budget-Balance and the Irrelevance Principle", Minh Viet, Economics Bulletin, vol. 29, no. 3, pp. 1885-1900, 2009.

[31] Pal, D., White, M. D., "Mixed Oligopoly, Privatization, and Strategic Trade Policy", Southern Economic Association, 
Southern Economic Journal, vol. 65, no. 2, pp. 264-281, 1998.

[32] Fjell, K., Heywood, J. S., "Public Stackelberg Leadership in a Mixed Oligopoly with Foreign Firms", Wiley-Blackwell, Australian Economic Papers, vol. 41, no. 3, pp. 267-281, 2002.

[33] Matsumura, T., "Stackelberg Mixed Duopoly with a Foreign Competitor", Wiley-Blackwell, Bulletin of Economic Research, vol. 55, no. 3, pp. 275-287, 2003.

[34] Chang, W. W., "Optimal Trade and Privatization Policies in an International Duopoly with Cost Asymmetry", Routledge, Journal of International Trade and Economic Development, vol. 14, no. 1, pp. 19-42, 2005.

[35] Chao, C. C., Yu, E. S. H., "Partial Privatization, Foreign Competition, and Optimal Tariff", Wiley-Blackwell, Review of International Economics, vol. 14, no. 1, pp. 87-92, 2006.
[36] Han, L., Ogawa, H., "Economic Integration and Strategic Privatization in an International Mixed Oligopoly", Mohr Siebeck, FinanzArchiv, vol. 64, no. 3, pp. 352-363, 2008.

[37] Ohnishi, K., "International Mixed Duopoly and Strategic Commitments", Springer, International Economics and Economic Policy, vol. 4, no. 4, pp. 421-432, 2008.

[38] Ohnishi, K., “A Three-Stage International Mixed Duopoly with a Wage-Rise Contract as a Strategic Commitment", Wiley-Blackwell, The Manchester School, vol. 78, no. 4, pp. 279-289, 2010.

[39] Fernández-Ruiz, J., "Managerial Delegation in a Mixed Duopoly with a Foreign Competitor", Minh Viet, Economics Bulletin, vol. 29, no. 1, pp. 90-99, 2009.

[40] Gunderson, M., "Earnings Differentials Between the Public and Private Sectors", Wiley-Blackwell, Canadian Journal of Economics, vol. 12, no. 2, pp. 228-242, 1979. 